\title{
Н.П. Таньшина
}

\section{ВЕНСКАЯ СИСТЕМА И ВЕНСКИЕ СОГААШЕНИЯ: ВЗГАЯА ИЗ ФРАНЦИИ}

Аннотация. В статье речь идет о восприятии Венской системы международных отношений во Франции в годы Июльской монархии (1830-1848). Если правящие либераль-орлеанисты были убеждены, что Франция должна придерживаться Венской системы, отказавшись от идеи «экспорта револючии», то иирокие круги французского общества усматривали в Венских договорах основную причину всех бед и несчастий Франиии и выступали за их упразднение. Это противоречие между народными чаяниями и умеренным внешнеполитическим курсом правительства во многом оказалось фатальным для режима Июльской монархии и стало одной из причин Револючии 1848 г.

Ключевые слова: Венская система, Июльская революиия 1830 г., король ЛуиФилипп Орлеанский, «наполеоновская легенда», «Realpolitik», идея невмешательства, «экспорт революции».

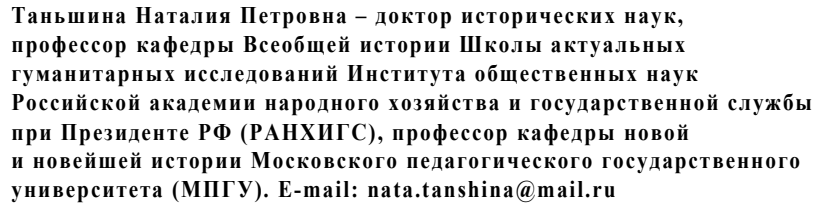

Таньшина Наталия Петровна - доктор исторических наук, профессор кафедры Всеобей истории Школы актуальных гуманитарных исследований Института общественных наук Российской академии народного хозяйства и государственной службы при Президенте РФ (РАНХИГС), профессор кафедры новой и новейшей истории Московского педагогического государственного университета (МПГУ). E-mail: nata.tanshina@mail.ru

\section{N.P. Tanshina. The Vienna System and the Vienna Agreements: The View} from France

Abstract. The article describes the perception of the Vienna system of international relations in France during the July monarchy (1830-1848). While the ruling liberal Orleanists were sure that France should follow the Vienna system, refusing the "export revolution" idea, the wide circles of the French society assumed that the Vienna treaties led to all disasters and misfortunes of France and stood for their abolition. Such conflict between people's aspirations and the moderate foreign policy of the government was really fatal for the regime of the July monarchy and became one of the reasons of the Revolution of 1848 . 


\section{РОССИЯ И МИР В ХІХ ВЕКЕ}

Keywords: the Vienna system, the July revolution of 1830, king Louis Philippe of Orleans, the "Napoleonic legend», "Realpolitik», the idea of non-interference, the «export of revolution».

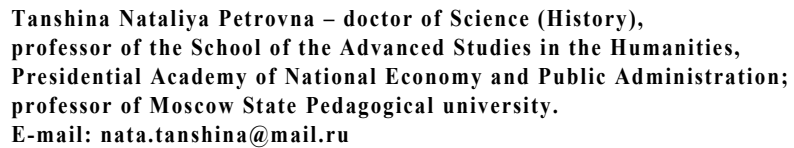

В истории XIX в. для французов есть два символических события с крайне негативной коннотацией - это Ватерлоо и Седан. Два символа унижения и позора. Ватерлоо завершило эпоху величия и побед императора Наполеона I, Седан подвел итог под империей его племянника, Наполеона III. Начиная с первых лет Реставрации в массовом сознании французов формируется убеждение, характерное для всего XIX в.: главным источником французских бед, и в первую очередь поражения Франции под Седаном, являются договоры 1815 г.

Между тем только Седан приучил французов к мысли о Ватерлоо. Все эти годы французы жили в плену «наполеоновской легенды» - идеи величия Франции, ее военного могущества и побед. «Наполеоновская легенда» была своеобразным противовесом Венским договорам, которые в глазах большей части французов являлись источником всех бед и несчастий Франции, синонимом ее национального унижения. И это притом, что Венские договоры отнюдь не имели такого унизительного характера для Франции. В этом была большая заслуга как князя Ш.-М. Талейрана, который, играя на противоречиях между державами, «выторговывал» выгодные для Франции условия, так и самих союзников, которые прекрасно осознавали, что Францию необходимо «проучить», но надо дать ей возможность вернуться в ранг «великих держав», дабы не создавать условий для развития реваншистских идей. Однако несмотря на то что уже в 1818 г. после уплаты контрибуции с территории Франции были выведены оккупационные войска, идея унижения, и соответственно, реванша, никуда не ушла из массового сознания. Напротив, она пустила глубокие корни и обильно расцвела. И случилось это в 1830 г., после Июльской революции, которая возродила не только чувство национальной гордости, но и чувство национальной обиды.

Июльская революция вызвала воспоминания о временах Великой революции и Империи, чувство необходимости ликвидировать договоры 1815 г., желание распространять за границы Франции идеи конституционного прогресса как противовес консервативным режимам. Эти ожидания, «это дно черной патриотической страсти» (как говорил политический деятель тех лет 
Шарль Ремюза), были широко распространены во французском общественном мнении: среди республиканцев и даже самих орлеанистов, интеллектуалов, студентов, либеральной буржуазии. Все критиковали правительство за то, что оно жертвует национальной честью в материальных и династических интересах правящей верхушки [10, p. 300]. Министра иностранных дел Франции в 1840-1848 гг. Франсуа Гизо именовали не иначе как «лордом Гизо», или «лордом Валь-Рише» (по наименованию его нормандского поместья), имея в виду его якобы проанглийскую политику. Даже национальная гвардия вотировала манифесты против пацифизма короля.

Такие настроения подогревались и событиями в Европе: Июльская революция 1830 г. стала катализатором революционных движений в Бельгии, Польше, Итальянских государствах. Король Луи-Филипп Орлеанский, сам пришедший к власти в результате революции, оказался в сложных условиях. Политика французских либералов-орлеанистов по отношению к разного рода революционным и национально-освободительным движениям - это один из деликатных аспектов французской дипломатии. С одной стороны, французы считали себя обязанными помочь народам, боровшимся за свое освобождение, а идея «экспорта революции», апробированная в конце XVIII в., вновь обрела огромную популярность. По словам современника событий Луи Блана, в эти годы «Франция жила больше жизнью других наций, чем своей собственной. События, будоражившие тогда Польшу, Португалию, Бельгию, занимали умы в манере почти исключительной...» [9, t. 2, p. 349]. С другой стороны, континентальные монархи пристально следили за действиями Франции и не простили бы Луи-Филиппу оказания восставшим поддержки. Король это понимал и был вынужден маневрировать, чтобы не дать погибнуть движениям, которым он симпатизировал. Можно сказать, что Луи-Филипп стремился по мере возможности «орлеанизировать» новые политические режимы, создавая, таким образом, дружественные Франции государства.

Польские, итальянские и немецкие беженцы, скрывавшиеся во Франции и бывшие там весьма популярны, также поддерживали идею освободительной миссии Франции. Ф. Гизо так говорил в своем парламентском выступлении 15 января 1831 г.: «Народ, совершивший революцию и принявший революционные принципы, должен сделать их превалирующими во всей Европе... Рассуждают так: принцип народного суверенитета восторжествовал у нас, значит, необходимо содействовать тому, чтобы он победил во всей Европе» [12, t. 1, p. 191]. Такую идею Гизо называл «фантазией» и отмечал, что она не являлась новой: «Людовик XIV ... имел фантазию сделать французскую монархию лидирующей в Европе; Конвент хотел доминирования республики; Бонапарт желал установления Империи во всей Европе. Священный союз претендовал подчинить ее абсолютному монархическому 
принципу. Что из этого вышло? Неистовая реакция не только правительств, но и народов, национальная реакция против намерения навязать Европе жесткое единство!» $[12$, t. 1, p. 191]. Исходя из этого, либералы-орлеанисты выдвинули принцип невмешательства во внутренние дела другого государства.

Идея невмешательства - это один из главных постулатов политики Сопротивления ${ }^{1}$. Умеренные либералы-орлеанисты сформулировали этот принцип в качестве противовеса идее Священного союза о легитимности вмешательства во внутренние дела государства, представляющего угрозу для существования абсолютистских режимов. Франция, в которой только что победила революция, объявляла, таким образом, нелегитимным вмешательство иностранных дворов в ее внутренние проблемы.

Глава правительства герцог В. де Брой, сравнивая принцип невмешательства с личной свободой, отмечал: «Я являюсь хозяином у себя, и никто не имеет права проникать ко мне без моего согласия... Если мой сосед намеревается вмешаться в мои дела, я не только имею право противодействовать его вмешательству, но вправе подавить его, призвав на помощь всех других моих соседей, имеющих косвенный, но легитимный интерес к сохранению свободы каждого человека и безопасности каждого жилища. Так и между государствами: каждый у себя, каждый за себя; все, по необходимости, за или против каждого, согласно обстоятельствам» [11, t. 4, p. 39].

Как видим, де Брой полагал, что принцип невмешательства отнюдь не означал пассивной линии поведения. Французское правительство брало на себя обязательство не вмешиваться во внутренние дела других государств. Оговаривая при этом, что если ситуация в какой-либо стране будет представлять угрозу национальной безопасности Франции, если во внутренние дела какого-либо государства вмешается третья держава и возникнет опасность для Франции или для европейского равновесия, то Франция может прибегнуть к вооруженному вмешательству в дела другого государства.

Исходя из такой интерпретации принципа невмешательства французское правительство осуществляло практические действия: в частности по вопросу о судьбе Бельгии. Такую трактовку этого принципа и сторонники политики Луи-Филиппа, и представители оппозиции называли «двойным принципом». По словам посла Российской империи во Франции графа К.О. Поццо ди Борго, «Франция, постоянно твердя о невмешательстве, без конца проводила противоположную политику». Российский дипломат считал, что Луи-Филипп тяготился необходимостью придерживаться принципа невмешательства и следовал ему только потому, что общественное мнение Франции было настроено

1. Сопротивление - это правый фланг орлеанизма, в отличие от Движения, занимавмего левый фланг.

64 
решительно в пользу этого принципа. По его мнению, король «не мог отказаться от идеи невмешательства без больших опасностей для себя самого» $[1$, л. 404].

Лидеры Сопротивления не были согласны с такой трактовкой принципа невмешательства. По словам Казимира Перье, одного из ведущих политиков тех лет, в 1831 г. возглавлявшего правительство, принцип невмешательства вовсе не означал обязательного присутствия французских войск повсюду, где этот принцип нарушался. «Это будет вмешательство другого рода», - заявил К. Перье, выступая в Палате депутатов 18 марта 1831 г. По его словам, такая политика означала бы «возобновление претензий Священного союза... химерических амбиций всех тех, кто хотел подчинить Европу одной идее и создать универсальную монархию. Трактуемый подобным образом принцип невмешательства будет служить прикрытием духа завоеваний» [2, л. 92 об.].

Проблема проживания на территории Франции эмигрантов из Польши, Италии, Испании была очень острой на всем протяжении существования Июльской монархии. Эта проблема вызывала осложнения как политического, так и экономического плана, поскольку содержание иностранцев значительно отягощало бюджет Франции, а также являлось фактором внутриполитической нестабильности. Например, в 1840 г., по данным Ш.-М. Дюшателя, министра внутренних дел в правительстве Н. Сульта, всего на территории Франции насчитывалось приблизительно 31800 иностранцев, из них испанцев - 26400 человек. По его мнению, правительству следовало принять меры для ограничения числа эмигрантов на территории Франции. В то же время он подчеркивал, что это было сделать не так уж просто. «Обстоятельства налагают на нас это тяжкое бремя по крайней мере до конца года», - заявил министр [16, p. 2298].

Французские власти в эти годы получали нескончаемые жалобы со стороны русского правительства по поводу пребывания поляков во Франции. Вице-канцлер граф К.В.Нессельроде обвинял французское правительство в покровительстве польским эмигрантам, в частности князю Адаму Чарторыйскому, усматривая в этом «великий скандал» и «скандальный беспорядок» [5, т. 15, с. 201]. Решить проблему пытались разными способами: от отправления поляков в Португалию до создания Польского легиона, однако эти попытки не увенчались успехом. В результате неблагонадежных поляков разместили подальше от столицы, в так называемых «польских депо».

В условиях роста патриотических настроений и обострения чувства национального самосознания даже обычные в дипломатической практике компромиссы воспринимались французами весьма болезненно. Что уж говорить о реакции французов на заключение 15 июля 1840 г. Лондонской конвенции по делам Востока без участия Франции! Это спровоцировало в стране бурю патриотического негодования, волну русофобских и англофобских настроений. 
Пока в правительстве пытались трезво оценить создавшуюся ситуацию, возмущенные парижане били стекла в британском посольстве и устраивали бурные манифестации на бульварах столицы; в стране уже мечтали о реванше за 1815-й год. По словам Гизо, «новая коалиция против Франции (имеются в виду державы, заключившие Конвенцию 15 июля 1840 г. - Н. T.) пробудила... еще живые воспоминания о наших битвах против могучих европейских коалиций и породила во Франции брожение, полное гнева и тревоги... При известиях о бедствиях, испытываемых Мухаммедом Али, в стране пробудилось в высшей степени воинственное движение, хотя трудно было определить его характер и масштабы; было лишь желание отомстить державам, которые воспользовались событиями на Востоке, чтобы восстановить против нас коалицию 1815 г. Однако вскоре из воинственного это движение превратилось в революционное. Политическая система Европы и основы французской монархии, границы государства и порядок вещей, существующий в других странах, - все эти вопросы возбуждены были разом; республиканская пресса отличалась обычным своим неистовством; тайные общества активизировали свою деятельность как никогда прежде...» [13, t. 5, p. 344, 382].

Во Франции начались лихорадочные военные приготовления. Были опубликованы королевские ордонансы, согласно которым все бессрочные отпускники призывались в действующую армию; численный состав армии значительно увеличивался. Было предписано сформировать 12 новых пехотных полков, десять стрелковых батальонов и шесть кавалерийских полков. Численность флотских экипажей была увеличена на 10 тыс. человек. На верфях в большом количестве строились новые корабли (пять линейных кораблей, 13 фрегатов и девять паровых судов). Был составлен комитет для разработки плана возведения укреплений вокруг Парижа, заседания которого происходили ежедневно. Как отмечал журнал «Русский вестник», не только во Франции, но и по всей Европе «господствовало убеждение, что стоило только французскому правительству открыть клапан, и революционный ураган распространился бы по Европе...» [6, с. 70].

Во французском общественном мнении было сильно убеждение, что именно тогда у Франции появилась реальная, может быть, единственная возможность попытаться трансформировать Венскую систему и не допустить превращения Франции во второстепенную державу. По словам Ф.Р. де Шатобриана, именно тогда глава правительства А. Тьер «держал в руках судьбы мира». Он упрекал главу кабинета в том, что ему «недостало решимости». Шатобриан писал: «Отдай он приказ напасть на английский флот, и при нашем тогдашнем численном превосходстве на Средиземном море победа была бы за нами; турецкий и египетский флоты, стоявшие в Александрийском порту, пришли бы нам на помощь; поражение Англии воодушевило бы Францию. Можно было сразу ввести стопятидесятитысячную армию в Баварию, 66 
можно было захватить какой-нибудь итальянский городок, не ожидающий нападения. Лицо всего мира изменилось бы» [7, с. 559-560]. Тьер, по его словам, «не решился пойти ва-банк; оценив свои силы, он их счел недостаточными, а ведь именно оттого, что ему нечего было терять, он мог все поставить на карту. Мы очутились под пятой у Европы: такого случая воспрянуть нам больше не представится» [7, с. 560].

Может быть, наиболее ярко национальное чувство проявится в ходе сопутствовавшего Восточному Рейнского кризиса - резкого обострения франко-немецких отношений.

На Венском конгрессе державы-победительницы не пошли на применение принципа легитимизма по отношению к германским землям. По сути, был сохранен порядок вещей, созданный Наполеоном I под новым названием Германский союз, находившийся под контролем Австрии и Пруссии. Французские либералы осудили эти решения, восстанавливавшие на Рейне систему, существовавшую к 1792 г., и оценивали решения Венского конгресса как угрожающие национальной безопасности Франции в будущем. По их мнению, главная задача французской внешней политики заключалась в возвращении Франции левого берега Рейна в качестве ее естественной границы и лучшей гарантии национальной безопасности страны. Как следствие, все усилия французской дипломатии должны были быть направлены на проведение и поддержку политических действий и движений, способных привести к упразднению системы, установленной Венским конгрессом. В этом отношении все группы французской оппозиции - от умеренных либералов до радикальных республиканцев и карбонариев - в годы Реставрации проявили единодушие.

В годы Восточного кризиса и изоляции Франции на международной арене в стране развернулось широкое движение за возвращение Франции левого берега Рейна, поддерживаемое даже окружением Луи-Филиппа. Левая газета «La Réforme» привела на своих страницах высказывание сына Луи-Филиппа, герцога Орлеанского, который на тот момент будто бы заявил: «Я лучше умру на берегах Рейна, чем в сточной канаве в Париже» [15]. Правда, ровно год спустя, вследствие трагического инцидента, он погиб буквально в парижской канаве...

Во французском обществе в то время были широко распространены иллюзии, что в тот момент, когда французские войска окажутся на Рейне, германское население встретит их с симпатией и надеждой как освободителей от деспотизма. Как справедливо отмечал французский исследователь Жак Дроз, французская общественность была твердо уверена, что «достаточно одного выстрела французской пушки, чтобы жители прирейнских городов поднялись против прусского господства» $[17$, p. 110]. Во Франции был живуч миф о приверженности немцев к Франции как к стране, являвшейся символом 
свободы и равенства всех людей. Антифранцузские заявления немецких газет расценивались как происки агентов Меттерниха; во Франции полагали, что эти сообщения не имели ничего общего с истинными настроениями германского общества. Однако именно Рейнский кризис показал, что надежды французов на привлекательность французской модели для германских государств и их стремление к союзу с Францией не были обоснованными.

На волне всплеска патриотических и национальных чувств Адольф Тьер, восторженный поклонник Наполеона и «наполеоновской легенды», затеял операцию, которую Виктор Гюго назвал «монументальной галиматьей» возвращение праха Наполеона с острова Святой Елены (12 мая 1840 г. английское правительство согласилось возвратить Франции останки Наполеона I). Французское общество пришло в состояние чрезвычайного возбуждения, в стране опять заговорили о победах, завоеваниях и естественных границах. Может быть, это было сделано намеренно: Тьер был убежден, что Франции нечего опасаться угрозы бонапартизма, и стремился доказать французам, что из всех политических деятелей Июльской революции именно он был самым пламенным патриотом.

Доставка тела Наполеона была возложена на третьего сына Луи-Филиппа, принца Жуанвильского. Сын короля вспоминал: «Я был солдатом, и я не мог оспаривать приказ». В своих мемуарах он отмечал, что рассматривал Наполеона под двойным углом зрения. С одной стороны, Наполеон для него являлся «врагом династии, убийцей герцога Энгиенского, который, терпя поражение, оставил Францию разрушенную, расчлененную, вовлекший ее в сомнительную азартную игру, где толпы наивных так часто становятся жертвами политических крупье, всеобщего избирательного права». С другой стороны, над этим Наполеоном «возвышался бесподобный военачальник, гений которого, даже в своем поражении, обессмертил наши армии». Принц отмечал, что он примирился с решением отца, воспринимая возвращение праха Наполеона как «возвращение знамени побежденной Франции, которое мы вновь поднимаем, по крайней мере, мы в это верим...» [14, p. 180].

На Святую Елену отправилась миссия, состоявшая, как писал принц Жуанвильский, из «свидетелей взлета и падения Наполеона», в том числе генералов Бертрана, Гурго, Лас-Каза. Во время путешествия велись настолько интересные разговоры: генералы вспоминали Наполеона, разные случаи из жизни, что принц Жуанвильский часто сожалел, что среди них не было стенографиста [14, p. 180-181].

Фрегат «Бель-Пуль» отправился на Святую Елену 7 июля и возвратился в Шербур 30 ноября: таково было распоряжение Тьера - прах Наполеона нужно было доставить в Париж к моменту открытия парламентской сессии. Однако Тьеру это не помогло: 29 октября Луи-Филипп сформировал кабинет во главе с Н. Сультом, в котором пост министра иностранных дел занял 68 
миролюбивый и склонный к компромиссам Ф. Гизо, фактически ставший реальным руководителем кабинета.

Последний этап водного пути - по Сене от Руана до парижского пригорода Курбевуа - останки Наполеона проделали на маленьком речном пароходе, и 14 декабря были выгружены на берег. Нос этого «погребального корабля» был украшен трехцветным знаменем и католическим крестом.

«Праздник почившего изгнанника, с торжеством возвращающегося на родину», как образно назвал церемонию Виктор Гюго, состоялся в Париже 15 декабря 1840 г. и, несмотря на опасения, прошел без эксцессов. Дело в том, что ультрапатриотическая антианглийская риторика, к которой летом и осенью 1840 г. охотно прибегали журналисты, верные Тьеру, оживила в народе память о поражениях 25-летней давности; парижские простолюдины вспомнили о Ватерлоо и стали вымещать обиду на англичанах, находившихся в Париже, от слуг до дипломатов. Перед церемонией 15 декабря ходили слухи, будто толпа намерена разгромить здание английского посольства; был известен случай, когда на улице Предместья Сен-Оноре толпа встретила экипаж английского посла во Франции криками: «Долой англичан!» [4, с. 346].

Очень интересные наблюдения об этом необычайно холодном по парижским меркам дне (в столице было минус десять) оставила Дельфина де Жирарден, регулярно публиковавшая свои очерки в газете «Пресса». В очерке от 20 декабря она писала: «На церемонии присутствовало шестьсот тысяч человек, и из этих шестисот тысяч всего две сотни оказались смутьянами, которые пытались нарушить торжественную тишину своими криками» [там же].

Сын короля принц Жуанвильский в своих воспоминаниях отмечал, что когда процессия двигалась по Елисейским Полям, раздались крики: «Долой изменников!» Поскольку он долго отсутствовал во Франции, то он сначала не понял, о чем идет речь. «Но мне объяснили, что эта манифестация была адресована моему отцу и его министрам, отказавшимся вовлечь Францию во всеобщую войну из-за событий на Востоке» [14, p. 193].

На площади перед Домом Инвалидов были устроены подмостки, на которых разместилось 100 тыс. человек; по обе стороны аллеи были установлены два ряда колоссальных статуй, изображавших героические фигуры, напротив Дома Инвалидов возвышалась гипсовая статуя императора. Однако в целом, по словам Гюго, в этой церемонии «не было правды, а потому и вышла она вся какой-то фальшью и надувательством. Правительство как будто испугалось вызванного им призрака. Показывая Наполеона, оно в то же время старательно скрывало его, намеренно оставляя в тени все, что было или слишком велико, или слишком трогательно. Грандиозная действительность всюду пряталась под более или менее роскошными покрывалами. Императорский кортеж, долженствовавший быть всенародным, ограничен одним 
военным, настоящая армия подменена Национальной гвардией, собор домашней капеллой Инвалидов, наконец, действительный гроб подменен пустым ящиком». Подменили, по словам Гюго, даже лошадь, белого коня, покрытого фиолетовым крепом, которого большинство принимало за настоящего боевого коня Наполеона, «не соображая, что если б он прослужил Наполеону хоть только два года, и то ему теперь было бы целых тридцать лет - возраст почти невозможный для лошади». На самом деле это была всем известная старая лошадь, которая вот уже десять лет фигурировала в роли боевого коня на всех парадных военных похоронах [3, с. 26, 37].

За гробом шли маршал Никола-Шарль Удино (наполеоновский маршал, в 1810 г. получивший от императора титул герцога Реджио), неся кисти от погребального покрова, маршал Молитор, генерал Бертран и адмирал Руссен.

Дельфина де Жирарден весьма точно подметила одну из главных причин популярности императора Наполеона I в массовом сознании французов. По ее словам, «он единственный был честен с народом, а не взывал к его рыцарскому великодушию и не обольщал его блистательными обманами». Она писала: «Наполеон сказал французам: “Сражайся за меня!” - и французы пошли за этим человеком с восторгом, и поклоняются его памяти по сей день, и будут поклоняться ей вечно, потому что он один понял их, он один не требовал от них никаких преступлений, он один не прививал им дурных страстей, он лишь приказывал им гибнуть с честью на поле боя, и они также повиновались бы» $[4$, с. 345$]$ - в этом, может быть, кроется и разгадка непопулярности ЛуиФилиппа, который призывал французов не к славе и смерти во имя побед, а к стабильности и умеренности.

«Как прекрасно было зрелище великодушного народа, с любовью приветствовавшего гроб победителя! Сколько рвения! Сколько волнения! Четырехчасовое ожидание под снегом ни у кого не отбило охоту присутствовать на церемонии» [там же]. Люди стояли вдоль всего пути следования погребальной колесницы; из порта Курбевуа кортеж добрался до Триумфальной арки на площади Звезды, оттуда процессия проследовала по Елисейским Полям до площади Согласия, пересекла Сену по мосту Согласия и направилась к Дому Инвалидов.

Через несколько дней после церемонии Дельфина де Жирарден писала: «Париж по сей день только и говорит, что о знаменательном событии. Все спрашивают друг у друга: “Ну и как вы все это вынесли?” Для того чтобы вынести все с начала до конца, требовалось в самом деле немалое мужество; недаром сразу после церемонии все кругом сделались больны. Все разговоры начинаются с жалоб; каждый перечисляет недуги, какими поплатился за присутствие на церемонии. Лишь затем начинается обмен впечатлениями» [4, c. 346]. 
Проницательная Дельфина де Жирарден очень тонко проследила процесс формирования «наполеоновской легенды»: «...История в конце концов примиряет своих детей со всем светом. Взять хотя бы этого подлого узурпатора, коварного корсиканца, отвратительного тирана, ненасытного людоеда, мерзкого крокодила; его проклинали, его ненавидели, ему изменяли, больше того, его забыли!.. И что же? Теперь те, кто его проклинали, им восхищаются, те, кто его ненавидели, ему поклоняются, те, кто ему изменили, его оплакивают, те, кто его осуждали, его воспевают... Какие удивительные превращения! А ведь прошло всего два десятка лет! Как! Неужели ненависть так непостоянна!..» [4, с. 348$]$.

В годы Июльской монархии во Франции столкнулись два подхода к решению внешнеполитических проблем: либеральный, проводимый либералами-орлеанистами, с приоритетом морали и права, и традиционнореалистический. Второй подход, популярный в широких слоях французского общества и среди части политического истеблишмента, подразумевал необходимость отстаивания национальных интересов страны всеми возможными методами, в том числе и силовыми. Если широкие круги французов были охвачены патриотическим чувством и были готовы ниспровергнуть Венскую систему, то Луи-Филипп, «король баррикад», пришедший к власти в ходе Июльской революции, исходил тем не менее из прямо противоположных установок. Король и поддерживавшие его либералы-орлеанисты полагали, что единственной возможностью для Франции быть вновь допущенной в «европейский концерт» являлись признание Венской системы международных отношений и легитимного порядка, установленного в Европе, а также отказ от идеи распространения либеральных принципов на штыках.

Представляется, что внешнеполитическая программа, предложенная либералами-орлеанистами, оказалась более реалистичной и прагматичной, исходящей из реальных экономических возможностей, военно-морского потенциала Франции и ее позиций в Европе. Орлеанисты, предполагая разрешение конфликта между конституционными и абсолютистскими державами, исходили из осознания того, что страх войны и революции лежали в основе недоверия, испытываемого европейскими государствами по отношению к Франции. Следовательно, чтобы Франция смогла занять достойное место «в европейском концерте», необходимо было убедить европейских монархов в ее миролюбии, в отсутствии у нее экспансионистских устремлений. Умеренные либералы полагали, что, несмотря на систему Венских договоров, ненавистную большинству французов, Франция остается великой державой, имеющей древнюю историю и высокий уровень интеллектуального потен- 
циала. Венский конгресс установил в Европе легитимный порядок, который лучше принять, чем постоянно с обидой оспаривать. В противовес общественному мнению орлеанисты полагали, что Франция должна действовать в русле договоров 1815 г., чтобы другие державы признали ее как силу мира и порядка, а не войны и разрушения. Они считали, что со временем, придерживаясь такой политической программы, Франция займет свое законное место в европейской системе. Гизо, выступая в Палате депутатов 29 января 1848 г., так говорил о внешнеполитической линии Франции: «Мы рассматриваем договоры 1815 г. как основу европейского порядка. Мы утверждаем, что эта политика соответствует интересам как Франции, так и Европы» $[12$, t. 5, p. 543].

Итогом такой политики, по мнению Гизо, будет независимость и усиление Франции; ей не нужно будет опасаться изоляции и искать союзника, потому что против нее не будет никакой враждебной коалиции. Она будет договариваться, согласно обстоятельствам, или с ансамблем великих держав, или с каждой державой в отдельности.

Гизо сожалел, что критика Венской системы начиная с 1815 г. стала во Франции символом патриотизма. По его мнению, тенденция выступать против договоров 1815 г. и считать, что цель внешней политики Франции состоит в их аннулировании, породила во Франции ложные надежды, а в остальной Европе - напрасные опасения. Он соглашался с тем, что со временем могут произойти изменения Венской системы. Но эти изменения, утверждал он, «могут быть легитимными только после их обсуждения и принятия всеми державами, подписавшими Венские договоры» [12, t. 5, p. 268].

В то же время Гизо, не призывая к ликвидации Венской системы, своими внешнеполитическими комбинациями, по сути, подготавливал ее распад. Среди этих комбинаций можно назвать политические действия в Бельгии, стремление создать Средиземноморскую лигу, заключение торговых договоров с пограничными государствами: Бельгией, Голландией и Пьемонтом, которые со временем могли трансформироваться в политические объединения. Между тем, согласно решениям Венского конгресса, эти государства должны были выполнять роль буфера и приглушать возможные экспансионистские намерения Франции.

Анализ внешнеполитического курса либералов-орлеанистов показывает, что либералы, учитывая зыбкость тогдашнего европейского порядка, исповедуя либеральные внешнеполитические принципы, зачастую должны были исходить в своих действиях из так называемой «Realpolitik» - политики, которая будет характерна для великих держав во второй половине XIX в. Следование принципам «реальной политики» можно расценивать как важнейший мировоззренческий факт, как весьма серьезный перелом в сознании французской политической элиты. И в этом переломе отчетливо проявилась связь 
творчества, новаторства и уважения традиций; разработка новых тактических приемов, начальный этап формирования новой стратегии внешней политики.

Следование принципам «Realpolitik» проявилось и в колониальной политике Франции. Политика, направленная на завоевание Алжира, порывала с либеральными идеями недопущения войны. Такая политика оправдывалась орлеанистами с позиций национальных интересов Франции, что было свойственно консерваторам. Кроме того, Луи-Филипп прекрасно понимал, что миролюбивая внешняя политика не по нраву большинству французов; как отмечал Виктор Гюго, осторожная внешняя политика Луи-Филиппа была «навязана» французскому народу, «у которого в его гражданских традициях было 14 июля, а в военных традициях - Аустерлиц». Осознавая это, король попытался направить неуемную энергию французов в русло колониальной экспансии. На командные посты были возвращены многие деятели Революции и Первой Империи, такие как Сульт, Мортье, Себастьяни, Жерар, Клозель, Савари, Вале, Бюжо, с пиететом относившиеся к культу и славе Наполеона и настроенные в пользу завоевательной политики. Луи-Филипп, заявивший о своем миролюбии, не мог удовлетворить их притязаний; в качестве «компенсации» он им предложил Алжир.

Следование принципам «политики интересов» объясняется и стремление орлеанистов к сближению во второй половине 1840-х годов с «идеологическими противниками» Франции: Австрией и Россией после охлаждения отношений с Великобританией из-за «испанских браков» ${ }^{2}$.

Однако противоречие между правительственным курсом и народными ожиданиями во многом оказалось фатальным для режима Июльской монархии. Именно внешняя политика стала предметом постоянных нападок на власть со стороны оппозиции, притом что для самой оппозиции эти нападки являлись лишь средством дискредитации правительства. Очень яркую и нелицеприятную характеристику поведения короля французов на внешнеполитической арене дал Ф.Р. де Шатобриан. Он писал: «Филипп - полицейский: Европа может плюнуть ему в лицо; он утирается, благодарит и показывает свое королевское удостоверение» [7, с. 553]. По словам Шатобриана, ЛуиФилипп «клянчил у соседних государей подтверждения своей власти, унижал родину, заставляя ее плестись в хвосте у Англии, превращая ее в заложницу...» [7, с. 555]. Однако, по словам Шатобриана, Луи-Филипп «по нраву Европе, и она пеняет нам за то, что мы его не ценим; Англия радуется, что мы

2. Имеются в виду брачные союзы между королевой Испании Изабеллой и гериогом Кадисским, а также ее сестрой инфантой Луизой-Фернандой и сыном Луи-Филиппа гериогом Монпансье, заключенные осенью 1846 г. и явивщиеся причиной обострения отношений между Францией и Великобританией и, по сути, краха «сердечного согласия». 


\section{РОССИЯ И МИР В ХІХ ВЕКЕ}

вслед за ней свергли короля; другие государи ненавидят законную монархию, ибо не сумели покорить ее своей воле» [7, с. 552].

В годы Июльской монархии, в условиях свободы прессы, внешняя политика была главным объектом критики Луи-Филиппа. Любое компромиссное или умеренное действие воспринималось не иначе как антинациональное, угодническое и преступное. Об этом прекрасно написал Оноре де Бальзак в своей «Истории парижской прессы», где обыграл ситуацию, связанную c «делом Притчарда» ${ }^{3}$. Незначительный в принципе эпизод стараниями средств массовой информации был раздут до трагедии вселенского масштаба, требующей возмездия ценой войны. Из-за «печальных глупостей», как называл этот инцидент Луи-Филипп, дело чуть было не дошло до военного конфликта.

Лидер династической левой О. Барро также отмечал, что «дело, взятое само по себе, не имело серьезного мотива для конфликта». Однако, по его мнению, следует учитывать и другие факторы: Франция еще не оправилась после поражения в Восточном вопросе и не забыла, что Великобритания ее «обманула», заключив Конвенцию 15 июля 1840 г. без ее участия, между двумя странами существовали значительные разногласия по вопросу о Праве осмотра ${ }^{4}$. И тогда становится понятным, почему «несчастные острова Тихого океана» явились причиной серьезного кризиса в англо-французских отношениях. Он писал: «Эти обстоятельства явились искрой, попавшей на горящие угли, достаточной для того, чтобы разжечь пожар с новой силой» $[8, \mathrm{t} .1$, p. 387]. Правда, стоит отметить, что и английская пресса постаралась в неменьшей степени.

При анализе внешнеполитических дискуссий следует учитывать, что критика внешнеполитического курса правительства оппозицией зачастую не носила конструктивного характера, а являлась средством борьбы за власть, дискредитацию правительства и его низвержение. Это можно отчетливо проследить на примере критики оппозицией линии на установление «сердечного согласия» с Великобританией: оппозиция обвиняла правительство в проведении антинациональной, пробританской политики, презрительно именуя его «министерством заграницы». Однако когда кабинет Сульта-Гизо (1840-1847)

3. Конфликт между Францией и Великобританией, связанный с установлением франиузского протектората над Таити. Английский миссионер Притчард, занимавший в свое время должность английского консула при королеве Таити Помаре, склонял жителей Таити к антифраниузским действиям, за что был арестован франиузскими моряками и выслан в Англию.

4. Имеются в виду Договоры о праве осмотра кораблей в целях борьбы с работорговлей. Между Франиией и Великобританией происходили сложные переговоры по этому вопросу. Французы усматривали в договорах очередное нарушение своих интересов, опасаясь, что англичане будут пользоваться правом осмотра кораблей с иелью нанесения ущерба франиузской торговле как таковой. 
в деле «испанских браков» пошел на конфликт с Англией, оппозиция рьяно принялась критиковать правительство уже за то, что якобы ради «семейного альянса» оно пожертвовало «самыми дорогими и важными» интересами Франции, а именно союзом с Великобританией. В частности, А. Тьер, тогда лидер левого центра, постоянно критиковавший правительство Сульта-Гизо именно за его приверженность «сердечному согласию», за принесение в жертву этому «сердечному согласию» национальных интересов Франции, теперь заявлял: «Союз с Англией является истинной политикой нашего времени, поскольку его главной целью является борьба за свободу народов и независимость всех государств Европы... Франция должна пропагандировать не идею завоевания, а идею защиты европейской свободы и достичь этого она может только в союзе с Англией» [18, t. 7, p. 410].

То что эта критика не носила конструктивного характера, со всей очевидностью продемонстрировали события Революции 1848 г. Республиканцы, прежде неистово критиковавшие правительство Луи-Филиппа за проведение слабой, угоднической и антинациональной политики, придя к власти, устами министра иностранных дел Альфонса Ламартина заявили о том, что Франция будет придерживаться Венских трактатов и отказывается от идеи «экспорта революции».

В области внешней политики орлеанизм явился первой попыткой сознательно приучить французов, живших в плену «наполеоновской легенды» величия Франции, ее лидирующего положения в Европе, к проведению компромиссной и взвешенной политики, учитывающей реальные возможности страны. Драма орлеанистов заключалась в том, что французское общество осознало приемлемость их внешнеполитического курса, или, по крайне мере, вынужденно примирилось с ним лишь после поражения 1870-1871 гг., когда Седан напомнил о Ватерлоо. Вплоть до 1870 г. инерция внешнеполитического экспансионизма, рожденная Революцией конца XVIII в. и наилучшим образом воплотившаяся в Наполеоновских войнах, продолжала будоражить французское общество. Подтверждением этому служит то обстоятельство, что в национальной памяти французов Наполеон III намного популярнее, нежели Луи-Филипп и в целом орлеанисты.

\section{Библиография}

1. Архив внешней политики Российской империи. Ф. 133. Оп. 469. Д. 197.

2. Архив внешней политики Российской империи. Ф. 133. Оп. 469. Д. 198.

3. Гюго В. Посмертные записки. 1838-1875. М.: Кучково поле-Гиперборей, 2007. 384 с.

4. Жирарден Д. Парижские письма виконта де Лоне. М.: Новое литературное обозрение, 2009. $728 \mathrm{c}$

5. Мартенс Ф.Ф. Собрание трактатов и конвенций, заключенных Россией с иностранными державами. СПб.: Тип. М-ва путей сообщения (А. Бенке), 1877-1905. Т. 1-15. 


\section{РОССИЯ И МИР В ХІХ ВЕКЕ}

6. Феоктистов Е.В. Русская политика на Востоке перед Крымской войной // Русский вестник. 1868. Т. 73.

7. Шатобриан Ф.Р. де. Замогильные записки. М.: Издательство им. Сабашниковых, 1995. $736 \mathrm{c}$.

8. Barrot O. Mémoires posthumes de Odilon Barrot. Paris: Charpentier, 1875-1876. V. 1-4.

9. Blânc L. Histoire de dix ans. 1830-1840. Paris: Pagnerre, 1848. T. 1-5.

10. Broglie G. L'Orléanisme. La ressourse libérale de la France. Paris: Librairie de l'Académique Perrin, 1981. $415 \mathrm{p}$.

11. Broglié V., duc de. Les Souvenirs, 1795-1870. Paris, 1886. V. 1-4.

12. Guizot F. L'Histoire parlementaire de la France. Paris: Michel Lévy Frères, 1863-1864. T. $1-5$.

13. Guizot F. Mémoires pour servir á l'histoire de mon temps. Paris: Michel Lévy Frères, 1858 1867. V. $1-8$.

14. Joinville, prince de. Vieux souvenirs. 1818-1848. Paris: Mercure de France, 2008. 418 p.

15. La Réforme. 1843. 15 Sept.

16. Le Moniteur universel. N 329. 1840. 24 Nov.

17. Ovsinska A. La politique de la France envers l'Allemagne à l'époque de la monarchie de Juillet. 1830-1848. Warszawa, 1974.

18. Thiers A. Discours parlementaires de M. Thiers. Paris: Calmann Lévy, 1879-1883. T. 1-15.

\section{References}

Arhiv vneshnej politiki Rossijskoj imperii. F. 133. Op. 469. D. 197.

Arhiv vneshnej politiki Rossijskoj imperii. F. 133. Op. 469. D. 198.

Barrot O. Mémoires posthumes de Odilon Barrot. Paris: Charpentier, 1875-1876. V. 1-4.

Blânc L. Histoire de dix ans. 1830-1840. Paris: Pagnerre, 1848. T. 1-5.

Broglie G. L'Orléanisme. La ressourse libérale de la France. Paris: Librairie de l'Académique Perrin, $1981.415 \mathrm{p}$.

Broglié V., duc de. Les Souvenirs, 1795-1870. Paris, 1886. V. 1-4.

Feoktistov E.V. Russkaja politika na Vostoke pered Krymskoj vojnoj // Russkij vestnik. 1868. T. 73.

Gjugo V. Posmertnye zapiski. 1838-1875. Moscow: Kuchkovo pole-Giperborej, 2007. 384 p.

Guizot F. L'Histoire parlementaire de la France. Paris: Michel Lévy Frères, 1863-1864. T. 1-5.

Guizot F. Mémoires pour servir á l'histoire de mon temps. Paris: Michel Lévy Frères, 18581867. V. $1-8$.

Joinville, prince de. Vieux souvenirs. 1818-1848. Paris: Mercure de France, 2008. 418 p.

Le Moniteur universel. N 329. 1840. 24 Nov.

La Réforme. 1843. 15 Sept.

Martens F.F. Sobranie traktatov i konvencij, zakljuchennyh Rossieju s inostrannymi derzhavami. Saint Petersburg: Tip. M-va Putej Soobshhenija (A. Benke), 1877-1905. Vol. 1-15.

Ovsinska A. La politique de la France envers l'Allemagne à l'époque de la monarchie de Juillet. 1830-1848. Warszawa, 1974.

Shatobrian F.R. de. Zamogil'nye zapiski. Moscow: Izdatel'stvo im. Sabashnikovyh, 1995. 736 p. Thiers A. Discours parlementaires de M. Thiers. Paris: Calmann Lévy, 1879-1883. T. 1-15. $728 \mathrm{p}$.

Zhirarden D. Parizhskie pis'ma vikonta de Lone. Moscow: Novoe literaturnoe obozrenie, 2009. 